\title{
The Effect of Motivation and Discipline on Employee Performance at Depok Mayor's Office
}

Lucia Maduningtias

Univesitas Pamulang

E-mail: madulucia07@gmail.com

(Received: June-2018; Reviewed: July-2018; Accepted: August-2018;

Avalaibel Online: August-2018; Published: September-2018)

This is an open access article distributed under the Creative Commons Attribution License

CC-BY-NC-4.0 @2018 by author (https://creativecommons.org/licenses/by-nc/4.0/)

\begin{abstract}
This human resource factor is an element that must be considered by each agency. The purpose of this study was to determine the effect of motivation and discipline on employee performance at the Depok Mayor's Office. The method used in this research is descriptive with an associative approach, the sampling technique used is proportional random sampling using the census or saturated sampling method with a sample of 50 respondents. The analysis tool uses instrument testing, classical assumption testing, regression testing, correlation coefficient testing and coefficient of determination and hypothesis testing. The results of the study concluded that there was a positive and significant effect both partially and simultaneously between motivation and discipline on employee performance at the Depok Mayor's Office. The level of influence or strength of the relationship simultaneously is 0.690 or strong with the contribution of influence of 0.476 or $47.6 \%$ while the remaining $52.4 \%$ is influenced by other factors. Hypothesis testing is obtained $F_{\text {count }}>F_{\text {table }}(21,230>2,800)$ thus $\mathrm{H} 0$ is rejected and $\mathrm{H} 3$ is accepted meaning that there is a positive and significant effect simultaneously between motivation and discipline on employee performance at Depok Mayor's Office
\end{abstract}

Keywords: Motivation; discipline; employee performance.

\section{INTRODUCTION}

Government agencies are organizations that are groups of people chosen specifically to carry out the tasks of the state, government, and development (Daswati \& Hattab, 2018; Ibrahim, 2018). Elemental Civil Servants who are domiciled provide services to the community in a professional, honest and equitable manner (Dewi, 2011; Fitriastuti, 2013; Sedarmayanti, 2011). Civil Servants must be neutral from the influence of all groups and political parties as well as discriminatory in providing services to the community based on loyalty and adherence to the Pancasila and the Undang-undang Dasar 1945 (Nurhajati \& Bachri, 2018; Pertiwi, 2017; Wardhani, Hasiolan, \& Minarsih, 2016). In an organization, the potential of Human Resources can be said to be the main resource because it can manage, analyze, and move the agency's goals effectively and efficiently. (Dessler, 2015; Handoko, 2011; Hasibuan, 2011). 
This human resource factor is an element that must be considered by every agency, including the Mayor of Depok. Agencies must be able to work more effectively, efficiently and productively. So humans can be seen as a determining factor because it is in the hands of humans that all innovations will be realized in an effort to realize the goals of government agencies (Rahadi, 2010; Rivai, 2005; Sedarmayanti, 2017). Taking into account the very important strategic role of human resources, the organization must utilize its human resources as effectively as possible in order to have good performance. One of them is by improving performance through employee discipline because discipline that is well managed will result in employee compliance with various rules set by the organization (Amiroso \& Mulyanto, 2015; Mangkunegara \& Octorend, 2015; Yg. \& Hutchison, 1989). To achieve its goals, high performance can be formed with the awareness of each leader to provide support to employees in the form of a leader's participation in providing direction regarding the work performed by each employee (Hasibuan, 2018; Rivai \& Mulyadi, 2012; Yudiaatmaja, 2013).

The Mayor of Depok is an agency that provides government, development and community services where the agency is expected to be able to provide maximum services to the public (Niswaty, Darwis, Alimuddin, \& Salam, 2016; M. S. Saggaf, Akib, Salam, Baharuddin, \& Kasmita, 2018; S. Saggaf, Salam, Kahar, \& Akib, 2014; Salam, 2015). Success in achieving agency goals will only be obtained if existing employees work with maximum performance. In the observation of researchers, the work motivation of Depok Mayor employees is not optimal, it can be seen from the problems, among others: not all employees in carrying out tasks on time, there are still employee jobs that have not been achieved in working, working only as a routine. Then seen from these problems the motivation of employees is very declining, causing performance in agencies is not optimal (Sunarsi, 2014, 2017, 2018a, 2018b, 2018c).

Based on the data obtained from the Depok mayor, this undisciplined employee is still seen from the level of absenteeism of the Depok mayor in the period 2014- below:

Figure 1.

Employee Attendance Graph

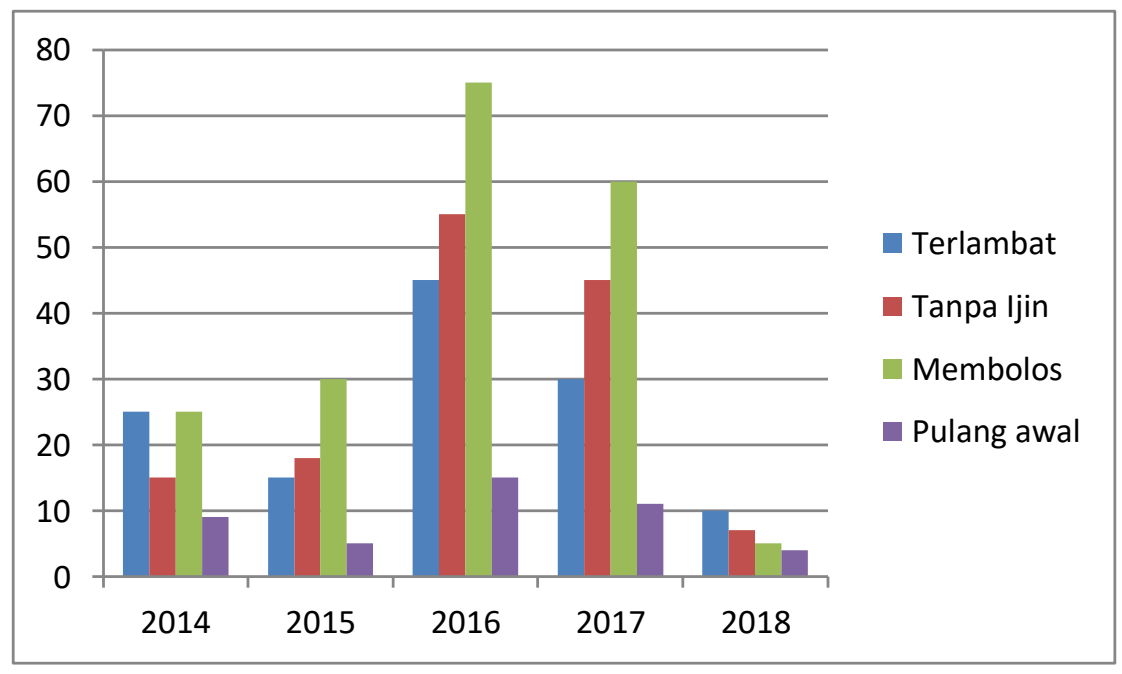

Based on the graph above, the absenteeism chart for employees over the past 5 years, the highest number of employees who are late, permits and without information is in 2015 while the lowest is in 2017. Then seen from absentee data on Depok Mayor employees fluctuate in 2014 to the year 2018. Furthermore, based on the performance evaluation of Depok Mayor's 
employees in 5 years the number of employees is 50 people, it can be seen in the following table:

Tabel 1.

Employee Performance Assessment Data Depok Mayor in 2014-2018

\begin{tabular}{|c|c|c|c|c|c|c|c|c|c|}
\hline Year & \multicolumn{2}{|c|}{$\begin{array}{c}\text { Improve services that are } \\
\text { effective, efficient and } \\
\text { transparent }\end{array}$} & \multicolumn{2}{c|}{$\begin{array}{c}\text { Improve the quality of } \\
\text { government management }\end{array}$} & \multicolumn{3}{c|}{$\begin{array}{c}\text { Improve workforce } \\
\text { competency and protection }\end{array}$} \\
\cline { 2 - 11 } & Target & Riil & $\%$ & Target & Riil & $\%$ & Target & Riil & $\%$ \\
\hline 2014 & 85 & 80 & 94,11 & 58 & 49 & 84,48 & 9,42 & 7,17 & 74,11 \\
\hline 2015 & 81,5 & 75,9 & 92,24 & 38,18 & 31,12 & 81,50 & 53 & 34 & 64,15 \\
\hline 2016 & 37,41 & 34,2 & 91,32 & 66 & 52,15 & 79,01 & 15 & 8 & 53,33 \\
\hline 2017 & 15 & 13,6 & 90,86 & 64 & 49,05 & 76,64 & 79,72 & 36,57 & 45,87 \\
\hline 2018 & 83,01 & 68,6 & 82,61 & 73,13 & 45 & 61,53 & 32,18 & 13 & 40,39 \\
\hline
\end{tabular}

Based on the above table, the employee performance appraisal at the Mayor of Depok in carrying out activities to increase services that are effective, efficient and transparent, improve the quality of government management, increase competency and workforce protection from 2014 to 2018 has decreased. As for the symptoms that arise from the lack of motivation that makes employees not obey the rules so that many come late and the number of work delayed which results in unfinished tasks which should be completed in one day to two days so that a lot of time is wasted, and also the lack of promotion to increase employees who have long periods of work so that the enthusiasm of work does not increase so that even very low and the lack of coaching of employees so that responsibility for the tasks given by the company is less well implemented.

\section{METHOD}

The type of data used is quantitative with primary data sources by distributing questionnaires which are then carried out tabulation and feasibility analysis as well as secondary data from the various scientific literature. The population in this study were Depok Mayor Office employees. Sampling was used saturation sampling technique that is 50 employees. The instrument testing uses validity and reliability tests. From the validity and reliability test stated valid and reliable, this is evidenced by the value of $r$ count $>r$ table, as well as the instrument used is appropriate and feasible to be forwarded to the next test. Testing for normality using Kolmogorov Smirnov obtained significance greater than 0.50 and thus declared normal. Multicollinearity testing obtained tolerance values $<1$ and VIF $<10$ so that it was concluded there was no interference with multicollinearity. Autocorrelation testing obtained the value of Durbin-Watson at an interval of 1.550 - 2.460, thus this regression model does not have autocorrelation. Heteroskesdastisitas testing with Glejser test obtained significance values greater than 0.05 so it was concluded that there was no interference with heteroscedasticity.

\section{RESULT AND DISCUSSION}

Verification analysis is intended to determine the magnitude of the influence and analyze the significance of the influence. In this analysis carried out on the influence of two independent variables on the dependent variable. partially or simultaneously. 


\section{Analisis Regresi Linear Berganda}

This multiple regression test is intended to find out how much influence the variables $\mathrm{X} 1$ and X2 on the Y variable. In this study Motivation (X1) and Discipline (X2) on Employee Performance (Y). Following are the results of processed regression data, as follows:

Table 2.

Results of Multiple Regression Processing

\section{Coefficients $^{\mathrm{a}}$}

\begin{tabular}{|c|c|c|c|c|c|}
\hline \multirow[b]{2}{*}{ Model } & \multicolumn{2}{|c|}{ Unstandardized Coefficients } & $\begin{array}{c}\text { Standardized } \\
\text { Coefficients }\end{array}$ & \multirow[b]{2}{*}{$\mathrm{t}$} & \multirow[b]{2}{*}{ Sig. } \\
\hline & $\mathrm{B}$ & Std. Error & Beta & & \\
\hline $1 \quad$ (Constant) & 10.345 & 4.365 & & 2.370 & .002 \\
\hline Motivation (X1) & .291 & .134 & .317 & 2.172 & .035 \\
\hline Discipline (X2) & .444 & .150 & .432 & 2.961 & .005 \\
\hline
\end{tabular}

a. Dependent Variable: Employee Perfoemance $(\mathrm{Y})$

Obtained a regression equation $Y=10,345+0,291 X 1+0,444 X 2$. A constant value of 10.345 means that if the variables X1 and X2 do not exist then there is a Betta value of 10,345 points. A value of 0.291 is interpreted if the constant is constant and there is no change in the $\mathrm{X} 2$ variable, then every 1 unit change in the $\mathrm{X} 1$ variable will result in a change in $\mathrm{Y}$ of 0.291 points. A value of 0.444 is interpreted if the constant is constant and there is no change in the $\mathrm{X} 1$ variable, then every 1 unit change in the $\mathrm{X} 2$ variable will result in a change in $\mathrm{Y}$ of 0.444 points.

\section{Analisis Koefisien Determinasi}

Analysis of the coefficient of determination is intended to determine the percentage strength of the relationship between the independent variables on the dependent variable both partially and simultaneously).

Table 3.

Results of Partial Determination Coefficient Analysis Between Motivation Variables (X1) Against Employee Performance (Y)

\begin{tabular}{|lrrrr}
\multicolumn{5}{|c}{ Model Summary } \\
\hline Model & $\mathrm{R}$ & R Square & Adjusted R Square & Std. Error of the Estimate \\
\hline 1 & $.615^{\mathrm{a}}$ & .378 & .365 & 3.033 \\
\hline
\end{tabular}

a. Predictors: (Constant), Motivation (X1)

Based on the table3, the R-square value (determination coefficient) of 0.378 is obtained, it can be concluded that the Motivation variable (X1) influences the Performance variable (Y) by $37.8 \%$ while the remaining $62.2 \%$ is influenced by other factors.

Table 4.

Results of Partial Determination Coefficient Analysis Between Disciplinary Variables (X2) Against Employee Performance (Y)

Model Summary

\begin{tabular}{llrrr}
\hline Model & $\mathrm{R}$ & $\mathrm{R}$ Square & Adjusted R Square & Std. Error of the Estimate \\
\hline 1 & $.650^{\mathrm{a}}$ & .423 & .411 & 2.921 \\
\hline a. Predictors: (Constant), Discipline (X2) & & &
\end{tabular}


Based on the table 4, an R-square value of 0.423 is obtained, it can be concluded that the discipline variable (X2) influences the employee performance variable $(\mathrm{Y})$ of $42.3 \%$ while $57.7 \%$ is needed by other factors.

Table 5.

Results of Simultaneous Determination Coefficient Analysis Between Variable Motivation (X1) and Discipline (X2) Against Employee Performance (Y)

Model Summary

\begin{tabular}{llllr}
\hline Model & $\mathrm{R}$ & $\mathrm{R}$ Square & Adjusted R Square & Std. Error of the Estimate \\
\hline 1 & $.690^{\mathrm{a}}$ & .476 & .453 & 2.814 \\
\hline a. Predictors: (Constant), Discipline & $(\mathrm{X} 2)$, Motivation (X1) & &
\end{tabular}

Based on the table 5, R-square value of 0.476 is obtained, it can be concluded that the Motivation (X1) and Discipline (X2) variables affect the Employee Performance variable (Y) of $47.6 \%$ while the remaining $52.4 \%$ is influenced by other factors which are not done the research.

\section{Hypothesis test}

To test the hypothesis of Motivation (X1) and Discipline (X2) variables on Employee Performance $(\mathrm{Y})$, it is performed with a statistical test $\mathrm{t}$ (partial test). In this study the significance criteria used 5\% (0.05). The results of data processing using SPSS Version 24, with the following results:

Table 6.

Motivation Variable T-Test Results (X1)

Coefficients $^{a}$

\begin{tabular}{|c|c|c|c|c|c|c|}
\hline \multirow{2}{*}{\multicolumn{2}{|c|}{ Model }} & \multicolumn{2}{|c|}{$\begin{array}{l}\text { Unstandardized } \\
\text { Coefficients }\end{array}$} & \multirow{2}{*}{$\begin{array}{c}\begin{array}{c}\text { Standardized } \\
\text { Coefficients }\end{array} \\
\text { Beta }\end{array}$} & \multirow[b]{2}{*}{$\mathrm{t}$} & \multirow[b]{2}{*}{ Sig. } \\
\hline & & $B$ & Std. Error & & & \\
\hline \multirow[t]{2}{*}{1} & (Constant) & 17.175 & 3.995 & & 4.299 & .000 \\
\hline & Motivation(X1) & .564 & .104 & .615 & 5.400 & .000 \\
\hline
\end{tabular}

a. Dependent Variable: Employee Perfoemance $(\mathrm{Y})$

Based on the table 6 , the value of $t_{\text {count }}>t_{\text {table }}$ or $(5,400>2,011)$ is also strengthened by the value of $\rho$ value $<$ Sig. 0.05 or $(0,000<0.05)$. Thus, $\mathrm{H} 0$ is rejected and $\mathrm{H} 1$ is accepted, this shows that there is a positive and partially significant effect between motivation on employee performance at the Depok Mayor's office. By generating motivation means agencies must have a competitive advantage that can provide added value to the performance that they do. Based on the number of 50 respondents who were the object of this study, they gave a variety of answers. It is known from a total of 10 statements submitted on the motivation variable. Overall for the motivation variable questionnaire (X1) an average score of 3.81 was obtained with good criteria. Of the four indicators that get the lowest ratting score is an indicator of working conditions which only reached a score of 3.76 . 
Table 7.

Discipline Variable T-Test Result (X2)

Coefficients $^{a}$

\begin{tabular}{|c|c|c|c|c|c|c|}
\hline \multirow{2}{*}{\multicolumn{2}{|c|}{ Model }} & \multicolumn{2}{|c|}{ Unstandardized Coefficients } & $\begin{array}{c}\text { Standardized } \\
\text { Coefficients }\end{array}$ & \multirow[b]{2}{*}{$\mathrm{t}$} & \multirow[b]{2}{*}{ Sig. } \\
\hline & & $B$ & Std. Error & Beta & & \\
\hline \multirow[t]{2}{*}{1} & (Constant) & 12.684 & 4.391 & & 2.888 & .006 \\
\hline & Discipline (X2) & .668 & .113 & .650 & 5.933 & .000 \\
\hline
\end{tabular}

Based on the table above, the value of $t_{\text {count }}>t$ table or (5.933>2.011) is also reinforced by the value of $\rho$ value $<$ Sig. 0.05 or $(0,000<0.05)$. Thus, $\mathrm{H} 0$ is rejected and $\mathrm{H} 2$ is accepted, this shows that there is a positive and partially significant effect between discipline on employee performance at the Depok Mayor's office. By increasing discipline, it means that agencies must have a competitive advantage that can add value to the performance that they do. This is evidenced by looking at the whole for the discipline variable questionnaire (X2) obtained an average score of 3.88 with good criteria. Of the three indicators that get the lowest ratting score is the attendance indicator which only reaches an average score of 3.83 .

To test the effect of motivation and discipline variables simultaneously on employee performance at the Depok Mayor's Office, the statistical test F (simultaneous test) with a significance of $5 \%$ was carried out.

Table 8.

Simultaneous Hypothesis (F-Test Results)

\begin{tabular}{llrrrrr}
\multicolumn{7}{c}{ ANOVA $^{\mathrm{a}}$} \\
\hline Model & & Sum of Squares & \multicolumn{1}{c}{ Df } & Mean Square & F & \multicolumn{1}{c}{ Sig. } \\
\hline 1 & Regression & 337.626 & 2 & 168.813 & 21.320 & $.000^{\mathrm{b}}$ \\
& Residual & 372.154 & 47 & 7.918 & & \\
& Total & 709.780 & 49 & & & \\
\hline
\end{tabular}

a. Dependent Variable: Employee Performance (Y)

b. Predictors: (Constant), Discipline (X2), Motivation (X1)

Based on the above table, the calculated $F_{\text {count }}>F_{\text {table }}$ or $(21.320>2,800)$ is also strengthened by the $\rho$ value $<$ Sig. 0.05 or $(0,000<0.05)$. Thus, $\mathrm{H} 0$ is rejected and H3 is accepted, this shows that there is a positive and significant simultaneous effect between motivation and discipline on employee performance at the Depok Mayor's Office. Performance is the result of the quality and quantity of work achieved by an employee in carrying out their duties in accordance with the responsibilities given to him. This is evidenced by looking at the responses of respondents as a whole for the employee performance variable questionnaire (Y) obtained an average score of 3.86 with good criteria. Of the five indicators that get the lowest ratting score is an indicator of work skills where it only reaches a score of 3.73.

\section{CONCLUSION}

Based on the results of the study, it was found that motivation has a positive and significant effect on employee performance with a contribution of $37.8 \%$ Discipline has a positive and significant effect on Employee Performance with an influence contribution of $42.3 \%$. Automation and Discipline have a positive and significant effect on Employee Performance Obtained a regression equation $\mathrm{Y}=10.345+0.291 \mathrm{X} 1+0.444 \mathrm{X} 2$. Hypothesis testing obtained 
the value of $F_{\text {count }}>F_{\text {table }}$ or $(21.230>2,800)$, it is also strengthened with a probability of 0,000 $<0.05$. Thus $\mathrm{HO}$ is rejected and $\mathrm{H} 3$ is accepted. This means that there is a positive and significant effect simultaneously between Motivation and Discipline on Employee Performance at Depok Mayor's Office.

\section{REFERENCES}

Amiroso, J., \& Mulyanto. (2015). Influence of Discipline, Working Environment, Culture of Organization and Competence on Workers' Performance through Motivation, Job Satisfaction (Study in Regional Development Planning Board of Sukoharjo Regency). European Journal of Business and Management. https://doi.org/ISSN 2222-1905 (Paper) ISSN 2222-2839

Daswati, D., \& Hattab, S. (2018). Behavior of Non-Governmental Organizations in Utilizing the Use of Loan Funds and Revenues of Urban Poverty Reduction Projects (P2KP). Jurnal Ilmiah Ilmu Administrasi Publik, 8(1), 53-60.

Dessler, G. (2015). Manajemen Sumber Daya Manusia. In Jakarta: Salemba Empat.

Dewi, A. K. (2011). Hubungan antara Kecerdasan Emosi dengan Kecemasana menghadapi pensiun pada Pegawai Negeri Sipil.

Fitriastuti, T. (2013). Pengaruh Kecerdasan Emosional, Komitmen Organisasional Dan Organizational Citizenship Behavior Terhadap Kinerja Karyawan. Jurnal Dinamika Manajemen.

Handoko, T. H. (2011). Manajemen Personalia dan Sumber Daya Manusia. Pengantar Manajemen.

Hasibuan. (2018). Manajemen Sumber Daya Manusia. In Manajemen Sumber Daya Manusia.

Hasibuan, M. S. P. (2011). Manajemen Sumber Daya Manusia. Edisi Revisi Jakarta: Bumi Aksara.

Ibrahim, I. (2018). The Effect of New Pattern of Level IV Leadership Training and Education Policy Implementation on Leadership Competence of Supervisory Officials in Gorontalo Provincial Government. Jurnal Ilmiah Ilmu Administrasi Publik, 8(2), 165-172.

Mangkunegara, A. P., \& Octorend, T. R. (2015). Effect of Work Discipline, Work Motivation and Job Satisfaction on Employee Organizational Commitment in the Company (Case Study in PT. Dada Indonesia). Universal Journal of Management. https://doi.org/10.13189/ujm.2015.030803

Niswaty, R., Darwis, M., Alimuddin, W., \& Salam, R. (2016). Pengaruh Penerapan Prinsip Good Governance terhadap Efektivitas Kerja Pegawai. Jurnal Ilmiah Administrasi Publik (JIAP), 95-100.

Nurhajati, W. A., \& Bachri, B. S. (2018). Pengembangan Kurikulum Diklat (Pendidikan dan Pelatihan) Berbasis Kompetensi dalam Membangun Profesionalisme dan Kompetensi Pegawai Negeri Sipil (PNS). Jurnal Pendidikan (Teori dan Praktik). https://doi.org/10.26740/jp.v2n2.p156-164

Pertiwi, F. (2017). Pengaruh Disiplin Kerja Terhadap Produktivitas Kerja Pegawai Negeri Sipil Di Kantor Dinas Perindustrian Perdagangan Koperasi Dan Umkm Provinsi Kalimantan Timur. eJournal Administrasi Negara.

Rahadi, D. R. (2010). Manajemen Kinerja Sumber Daya Manusia. In Applied Physics A: 
Materials Science and Processing. https://doi.org/10.1007/s00339-002-1913-7

Rivai, V. (2005). Manajemen Sumber Daya Manusia Untuk Perusahaan : dari Teori ke Praktik. In Edisi Pertama, Penerbit PT. Raja Grafindo Persada, Jakarta. https://doi.org/10.1371/journal.pone.0013666

Rivai, V., \& Mulyadi, D. (2012). Kepemimpinan dan Perilaku Organisasi. In Kepemimpinan dan Perilaku Organisasi.

Saggaf, M. S., Akib, H., Salam, R., Baharuddin, A., \& Kasmita, M. (2018). The Quality Analysis Of Academic Services.

Saggaf, S., Salam, R., Kahar, F., \& Akib, H. (2014). Pelayanan Fungsi Administrasi Perkantoran Modern. Jurnal Ad'ministrare, 1(1), 20-27.

Salam, R. (2015). Pelayanan Fungsi Administrasi Perkantoran Modern Sebagai Basis Persaingan Masyarakat Ekonomi Asean (MEA) 2015. Seminar Nasional Dies Natalis UNM ke-54 "Peran Pendidikan Karakter Melalui Optimalisasi IPTEK Pencerdasan Generasi Unggul.

Sedarmayanti. (2011). Reformasi Birokrasi dan Manajemen Pegawai Negeri Sipil. In Manajemen Sumber Daya Manusia.

Sedarmayanti. (2017). Manajemen Sumber Daya Manusia. In Manajemen Sumber Daya Manusia.

Sunarsi, D. (2014). Pengaruh Gaya Kepemimpinan, Disiplin dan Motivasi Terhadap Kinerja. Tesis. Fakultas Ekonomi Universitas Pamulang.

Sunarsi, D. (2017). Pengaruh Disiplin, Motivasi, Dan Kompetensi Terhadap Prestasi Belajar (Studi Kasus Pada Mahasiswa Universitas Pamulang, Tangerang Selatan Tahun Akademik 2016-2017). Jurnal Mandiri: Ilmu Pengetahuan, Seni, dan Teknologi, 1(2), 207-226.

Sunarsi, D. (2018a). Pengaruh Gaya Kepemimpinan, Motivasi Dan Disiplin Kerja Terhadap Kinerja Pendidik Yayasan Marvin. Inovasi, 5(1), 1-18.

Sunarsi, D. (2018b). Pengaruh Gaya Kepemimpinan dan Disiplin Kerja Terhadap Kinerja Karyawan Pada CV. Usaha Mandiri Jakarta. JENIUS, 1(2).

Sunarsi, D. (2018c). Pengaruh Motivasi Dan Disiplin Terhadap Produktivitas Kerja Karyawan Pada PT. Nadi Suwarna Bumi. Jurnal Semarak, 1(1).

Wardhani, A. P., Hasiolan, L. B., \& Minarsih, M. M. (2016). Pengaruh Lingkungan Kerja, Komunikasi dan Kepemimpinan Terhadap Kinerja Pegawai ( Studi kasus di Dinas Kebudayaan dan Pariwisata Kota Semarang). Journal Of Management.

Yg., C. A. B. O., \& Hutchison, W. R. (1989). Positive discipline. Human Resource Management. https://doi.org/10.1002/hrm.3930280306

Yudiaatmaja, F. (2013). Kepemimpinan: Konsep; Teori dan Karakternya. Media Komunikasi. 